\title{
Microbial induced acid corrosion from a field perspective - Advances in process understanding and construction material development
}

\author{
Cyrill Grengg, ${ }^{1,}$, Florian Mittermayr ${ }^{2}$, Neven Ukrainczyk $^{3}$, Eddie Koenders ${ }^{3}$, Günther Koraimann ${ }^{4}$, Sabine \\ Kienesberger ${ }^{4,5}$ \& Martin Dietzel $^{1}$ \\ ${ }^{1}$ Institute of Applied Geosciences, Graz University of Technology, Rechbauerstraße 12, 8010 Graz, Austria \\ ${ }^{2}$ Institute of Technology and Testing of Building Materials, Graz University of Technology, Inffeldgasse 24, 8010 Graz, Austria \\ 3Institute of Construction and Building Materials, Technische Universität Darmstadt, Franziska-Braun-Straße 3, 64287 Darmstadt, \\ Germany \\ ${ }^{4}$ Institute of Molecular Biosciences, University of Graz, Humboldstraße 50, 8010, Graz, Austria \\ ${ }^{5}$ BioTechMed-Graz, Mozartgasse 12/II, 8010, Graz, Austria
}

\begin{abstract}
Microbial induced acid corrosion is accounted for $\sim 40 \%$ of the degradation of subsurface wastewater infrastructure globally. While fundamental process understanding has increased significantly within the last decades, to date no sustainable building material exists, which meets the long-term requirements in such aggressive and corrosive environments. This work describes a novel model based on field studies, conducted in various Austrian sewer networks, intertwining biological, mineralogical and hydro-chemical factors. Additionally, an extensive field testing campaign over the duration of 18 months, conducted on different geopolymer concretes (GPC), particularly designed for the latter environments will be presented. Innovative GPCs were tested regarding their microstructural behavior, microbial accessibility and hydro-chemical alterations over time and compared to commercially produced cement based products, including OPC and CAC concretes. Additionally, the system specific environmental parameters, such as relevant gas concentrations $\left(\mathrm{H}_{2} \mathrm{~S}, \mathrm{CO}_{2}, \mathrm{CH}_{4}\right)$, relative humidity and temperature were constantly monitored.
\end{abstract}

\section{Introduction}

The efficient, safe and cost-effective collection and transport of sewage is a key criterion maintaining expected sanitary standards of modern society [1]. Approximately $40 \%$ of concrete failure in sewer systems can be directly attributed to microbial induced concrete corrosion (MICC) [2]. Accordingly, MICC is recognized as one of the main degradation processes of subsurface infrastructure worldwide with high economic relevance $[3,4]$. To date cconventional building materials do not meet stipulated requirements for sustainable construction materials in the latter environments. Reasons therefore are multifaceted. Although process understanding has increased significantly within the last decades, in depth understanding of the microorganisms-concrete interactions is still lacking. Limited information is found in the literature describing MICC processes drawn from field studies and field observations. This work presents a new conceptual model describing crucial process aspect within advanced MICC, from a field perspective, intertwining analytics of spatial microbial distributions with chemical, mineralogical and (micro)structural related aspects [5]. Gained in depth knowledge of the physicochemical construction material characteristics and their impact regarding biofilm adhesion, development and structure form the basis for continuative development of suitable materials.

Accordingly, an extensive field campaign is presented in which innovative geopolymer concretes (GPC) were tested in respect to their overall performance in MICC environments, compared to conventional ordinary Portland and CAC cement based concrete materials. Due to their geopolymer characteristics, they potentially combine positive properties of vitreous ceramics (acid, permeability and abrasion resistance) with advanced performance of concrete pipes (low temperature molding, no dig repair, any pipe diameter possible), while overcoming their individual specific limitations at the same time (Ceramic: brittle, small diameters, dig renewal, higher cost; OPC-based Concrete: low durability) [6]. In contrast to existing concepts for concrete durability based on neutralisation by an inevitable dissolution of concrete, geopolymers are acid resistant [7], and are expected to provide a much longer-lasting and thus highly stable barrier against MICC, while acting as an implicit pipe protection.

* Corresponding author: cyrill.grengg@tugraz.at 


\section{Study site, materials and methods}

\subsection{Extraction and characterisation of concrete samples from manholes}

Concrete pre cast elements with the dimensions of several $10^{\text {th }}$ of $\mathrm{cm}$ were extracted from manholes of a heavily corroded sewer system during remediation work. Samples were stabilized using a two-component epoxy resin. Subsequent mineralogical and microbiological analytics were performed as described in detail by Grengg et al. (2017). In brief, thick sections containing the up to $4 \mathrm{~cm}$ thick corrosion layers were prepared for high resolution light microscopy and EPMA elemental mappings and high resolution spot analyses using microXRD. DNA isolation, PCR amplifications and sequencing were performed on concrete extracted from the interior and rim areas of the deteriorated corrosion layers. In order to visualize the microbial distribution within the deterioration layers fluorescent staining and imaging was performed. A detailed description of the sewer system, including concrete properties, corrosion rates, wastewater chemistry, microbial aspects and interstitial fluid chemistry has been recently described in [8]. A schematic description of the analytical methods applied for the model generation is presented in Fig. 1.

\subsection{Material characteristics}

Geopolymer mortars and geopolymers mortars containing copper sulfate (GP and GPCu) were casted together with conventional mortars, based on ordinary Portland cement (PC) and calcium aluminate cement (CAC). The chemical composition of the raw materials is given in Table 1. The used $\mathrm{K}$-waterglass had a solid content of 44 wt. $\%$, viscosity of $20 \mathrm{mPa}$ s, pH of 13.5 , and $\mathrm{SiO}_{2} / \mathrm{K}_{2} \mathrm{O}$ molar ratio of 1.5 . The cement produced is a Portland cement CEM I 52.5 R-SR3/NA. Calcium aluminate cement used contained $\mathrm{CaAl}_{2} \mathrm{O}_{4}$ as main clinker phase and following minor phases $(\mathrm{CaO})_{2}\left(\mathrm{Al}_{2} \mathrm{O}_{3}\right)\left(\mathrm{SiO}_{2}\right),(\mathrm{CaO})\left(\mathrm{TiO}_{2}\right)$ and $(\mathrm{CaO})_{12}\left(\mathrm{Al}_{2} \mathrm{O}_{3}\right)_{7}$. Blain values for powder raw materials are: $4390 \mathrm{~cm}^{2} / \mathrm{g}$ (PC); $3550 \mathrm{~cm}^{2} / \mathrm{g}$ (CAC); $26000 \mathrm{~cm}^{2} / \mathrm{g}$ (Metakaolin).

The mix design of the mortars is presented in Table 2. Geopolymers were manufactured using the above metakaolin and potassium based silicate solution. The effect of antimicrobial metal additive $\left(\mathrm{Cu}^{2+}\right)$ was investigated as well. Mortar standard specimens (size of 160x40x40 mm) were prepared according to EN-196-1, and subsequently cut in half $(80 \times 40 \times 40)$. Workability spread and compression tests were done according to EN 1015-(3 and 11). Specimens were cured for minimum of 28 days at $100 \%$ r.h. and $20^{\circ} \mathrm{C}$.

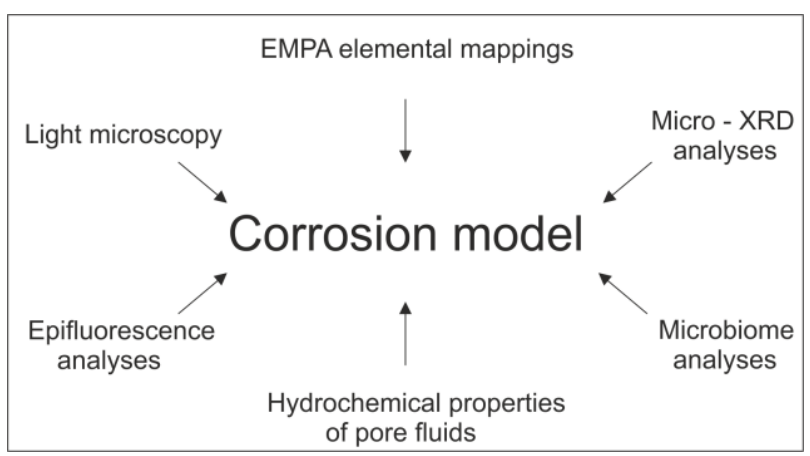

Fig. 1. Analytical methods feeding into the corrosion model.

The mercury intrusion porosimetry (MIP) measurements were carried out with Pascal 440 from Thermo-Scientific. Each specimen was weighted and surface $\mathrm{pH}$ measurements were conducted using an Extech PH100 flat surface electrode.

\subsection{Field study setup and analytical methods}

Newly designed geopolymer concrete specimen were outsourced together with OPC-based materials, into a sewer system heavily affected by MICC. In order to evaluate system characteristics, concentrations of hydrogen sulfide $\left(\mathrm{H}_{2} \mathrm{~S}\right)$ and temperature were monitored using a myDataSens $1000 \mathrm{H}_{2} \mathrm{~S}$ gas monitor. Monitoring relative humidity (r.h.) of the sewer atmosphere was realized by using a Voltcraft DL-121TH data logger.

Samples were taken after 3, 6, 9 and 12 months. Immediately after extraction, one side of each sample was scratched, in order to gain material for further microbial community structure analyses (data not shown). Thereafter, the specimens were dried by $40^{\circ} \mathrm{C}$ for $24 \mathrm{~h}$ followed by surface $\mathrm{pH}$ and weight was measurements. In addition, optical and high resolution microscopy imaging were performed, using a Keyence VHX-5000 Digital-Microscope. Finally, specimens were embedded into a two-component epoxy resin (Buehler; EpoThin 2 Hardener) and thick sections were prepared for further microstructural and microbiological analyses, which are currently, performed (data not shown).

Table 1 : Chemical composition (wt \%) of raw materials.

\begin{tabular}{|l|l|l|l|l|l|l|l|l|l|}
\hline Material & $\mathrm{SiO}_{2}$ & $\mathrm{Al}_{2} \mathrm{O}_{3}$ & $\mathrm{CaO}$ & $\mathrm{Fe}_{2} \mathrm{O}_{3}$ & $\mathrm{MgO}$ & $\mathrm{Na}_{2} \mathrm{O}$ & $\mathrm{K}_{2} \mathrm{O}$ & $\mathrm{SO}_{3}$ & $\mathrm{H}_{2} \mathrm{O}$ \\
\hline PC (CEM I) & 21.4 & 3.7 & 64.6 & 4.6 & 0.8 & 0.3 & 0.4 & 1.5 & - \\
\hline CAC & $>6$ & 50 & 40 & $<2.5$ & $<1.5$ & - & - & $<0.4$ & - \\
\hline Metakaolin & 55 & 41 & $<0.1$ & $<1.4$ & $<0.1$ & $<0.05$ & $<0.4$ & $<0.05$ & - \\
\hline Waterglass & 22 & & & & & & 23 & & 55 \\
\hline
\end{tabular}


Table 2 : Mix design of mortars (in grams).

\begin{tabular}{|l|l|l|l|l|l|l|l|}
\hline Material & CEM I & CAC & $\mathrm{H}_{2} \mathrm{O}$ & MK & Sand & Waterglass & $\mathrm{CuSO}_{4} * 4.5 \mathrm{H}_{2} \mathrm{O}$ \\
\hline PC & 450 & - & 225 & - & 1350 & - & - \\
\hline CAC & - & 450 & 225 & - & 1350 & - & - \\
\hline GP & - & - & - & 400 & 1350 & 425 & - \\
\hline GP-Cu & - & - & - & 400 & 1350 & 425 & 18.93 \\
\hline
\end{tabular}

\section{Results and Discussion}

\subsection{A new conceptual model for MICC Corrosion}

As presented by Grengg et al. (2017) the novel model intertwined biological, mineralogical and hydrochemical factors, which resulted in a dynamic micro-system, dominated by ongoing mineral dissolution and reprecipitation and subordinated microbial distribution, ultimately controlled by $\mathrm{pH}$ and aqueous diffusion [5]. Element mappings of $\mathrm{Al}, \mathrm{Ca}, \mathrm{Fe}, \mathrm{Mg}, \mathrm{S}$ and $\mathrm{Si}$ throughout these corrosion fronts revealed a clearly defined element succession path controlled by diffusion of dissolved species and $\mathrm{pH}$ (Fig. 2.). The cementitious matrix of non-corroded concrete was dominated by $\mathrm{Ca}$ and $\mathrm{Si}$ rich phases like portlandite $(\mathrm{Ca}(\mathrm{OH}) 2)$ and calcium silicate hydrates (C-S-H phases), framing siliceous and carbonate aggregates. The transition zone (TZ) between non-corroded and strongly affected concrete was characterized by an extreme drop in $\mathrm{pH}$ from 13 to below 1 with a reaction front of around $1 \mathrm{~mm}$ (for detail on pore fluid chemistry see Grengg et al. 2015). This reaction front is characterized by dynamic dissolution and precipitation reactions, determined by single mineral stability ranges which could be observed in element distributions and high resolution spot analyses of the mineralogical compositions. Opposed to current hypothesis $[9,10]$ microorganisms within this system were not limited to the uppermost layers of the deteriorated concrete, but were distributed throughout the entire corrosion front [5]. Acidithiobacillus ferrooxidans was isolated from the deteriorated concrete and could be linked with $\mathrm{Fe}$ accumulation zones within the deeper, anoxic to anaerobic corrosion layers, thereby proving $\mathrm{H}_{2} \mathrm{SO}_{4}$ production on site at and close to the corrosion front thus strongly affecting corrosion dynamics. Thereby, $\mathrm{Fe}^{3+}$, present in iron hydroxides and sulfates, e.g. goethite and lepidocrocite, gets reduced to $\mathrm{Fe}^{2+}$ during oxidation of reduced sulfur compounds at strongly acidic conditions [5].

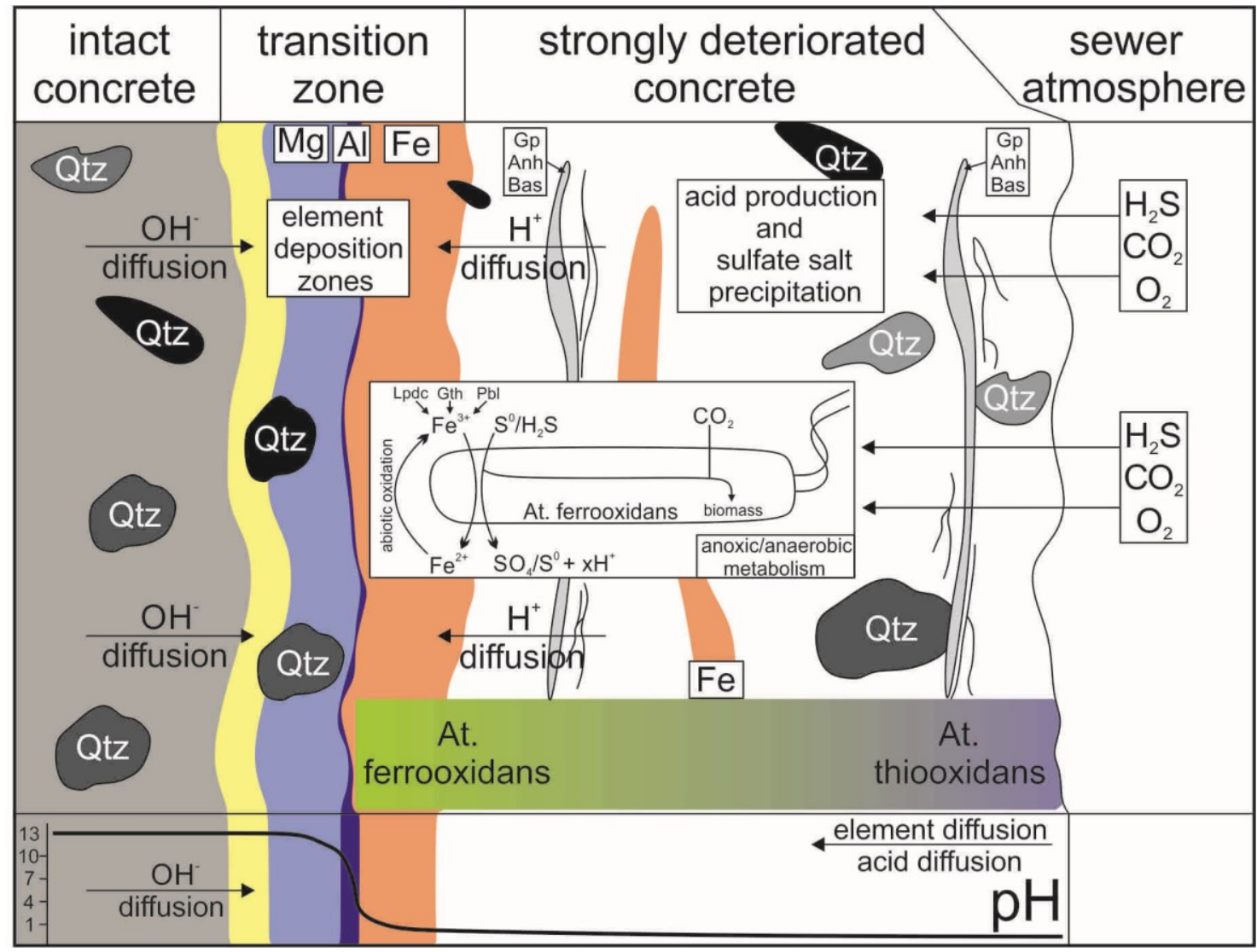

Fig. 2. $\mathrm{pH}$ and diffusion controlled corrosion model. Showing the succession of element accumulations together with associated microbiological activity within a progressive corrosion front (from the left to the right side), together with the relevant mineralogical, biological and material related inputs [5]. 


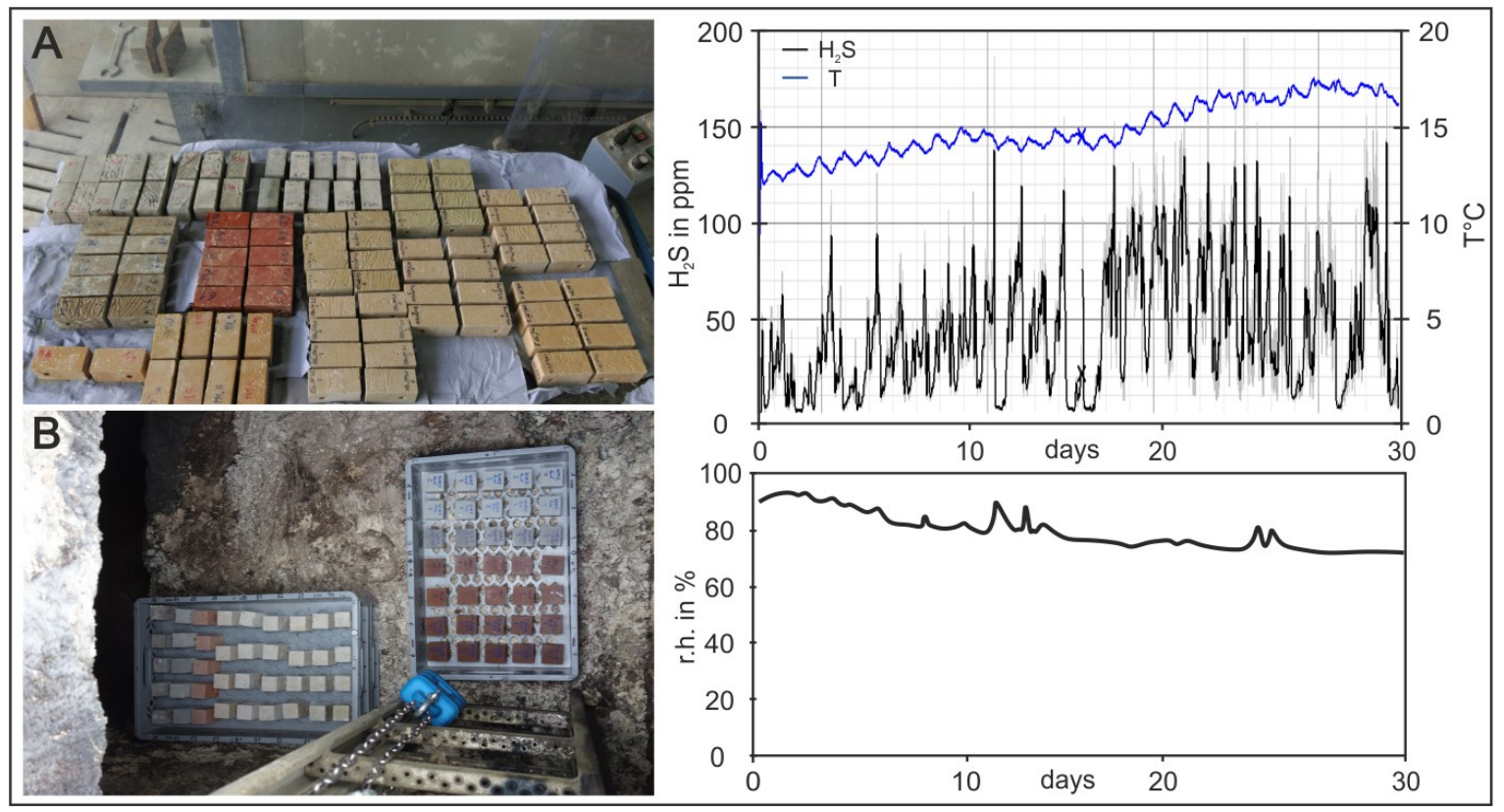

Fig. 3. Shows specimen preparation (A) and subsequent outsourcing into a system strongly affected by MICC (B). On site, $\mathrm{H}_{2} \mathrm{~S}$, temperature (T) and relative humidity (r.h.) was monitored.

Accordingly, the central role of iron regarding bioreceptivity and associated durability of concrete affected by MICC should be emphasized. Accordingly, we propose a model, where Acidithiobacillus thiooxidans dominated the oxygen rich zones close to the surface, while Acidithiobacillus ferrooxidans adopted the pore spaces within deeper, anoxic, corrosion layers (Fig. 2.). In fact, described in situ acid production at and close to the corrosion front has to be recognized as one central factor, steering high corrosion rates of about $1 \mathrm{~cm} \mathrm{yr}^{-1}$ and associated failure of parts of the sewer system after a service life of 10 years $[5,8]$.

\subsection{Advances in material development}

Casted specimens were outsourced into a sewer system, strongly affected by MICC. Average $\mathrm{H}_{2} \mathrm{~S}$ concentrations present were $44 \mathrm{ppm}$ with maximum concentrations up to $206 \mathrm{ppm}$. Relative humidity (r.h.) ranged between 98 and $78 \%$ (Fig. 3.). A positive correlation between $\mathrm{T}$ and $\mathrm{H}_{2} \mathrm{~S}$ concentrations could be observed, corresponding to higher bacterial activities with increasing $\mathrm{T}$, accompanied by a corresponding decrease in r.h.. Preliminary results showed considerably better performances of GPC, compared to conventional ordinary Portland cement-based (OPC) material after an exposure period of up to 12 months in sewer systems strongly affected by MICC. While no structural damage was observed on the GP specimen, strong deterioration was visible on the surfaces of the OPC-based reference material (Fig. 4.). There, process related acid production caused strongly decreasing surface $\mathrm{pH}$ levels and associated dissolution of the cementitious matrix, accompanied by gypsum precipitation finally resulting in intensive structural degradation. CAC concrete tested showed significant better performances as well when compared to OPC-based reference material, although initial structural surface degradation could be observed, resulting in surficial crack formation and transformation of cementitious matrix into secondary sulfate salts. Accordingly, a preliminary performance evaluation was ranked $\mathrm{GPC}>\mathrm{CAC}>\mathrm{OPC}$ materials. The impact of antimicrobial agents on biofilm development and associated material durability, together with microstructural analytics using electron microprobe, $\mathrm{pH}$ mappings and microbiological community analytics are at this time under evaluation and will be presented and discussed.

\section{CONCLUSION \& OUTLOOK}

The application of an interdisciplinary approach including mineralogical, chemical and biological aspects within a field application was described within a new model for advanced MICC. This model proposes a dynamic micro-system, dominated by ongoing mineral dissolution and re-precipitation and subordinated microbial distribution, controlled by $\mathrm{pH}$ and diffusion. Thereby, the interaction between microbes and cementitious materials is seen as the central process steering maintenance of mineral-based construction materials in sewer applications. Accordingly, the prevention of the latter is crucial for MICC mitigation. Gained in depth knowledge of the physicochemical construction material characteristics and their impact regarding biofilm adhesion, development and structure form the basis for continuative development of suitable materials. In this context, geopolymer based construction materials exhibit great potential as an alternative, highly stable construction material for aggressive sewer systems [6]. 


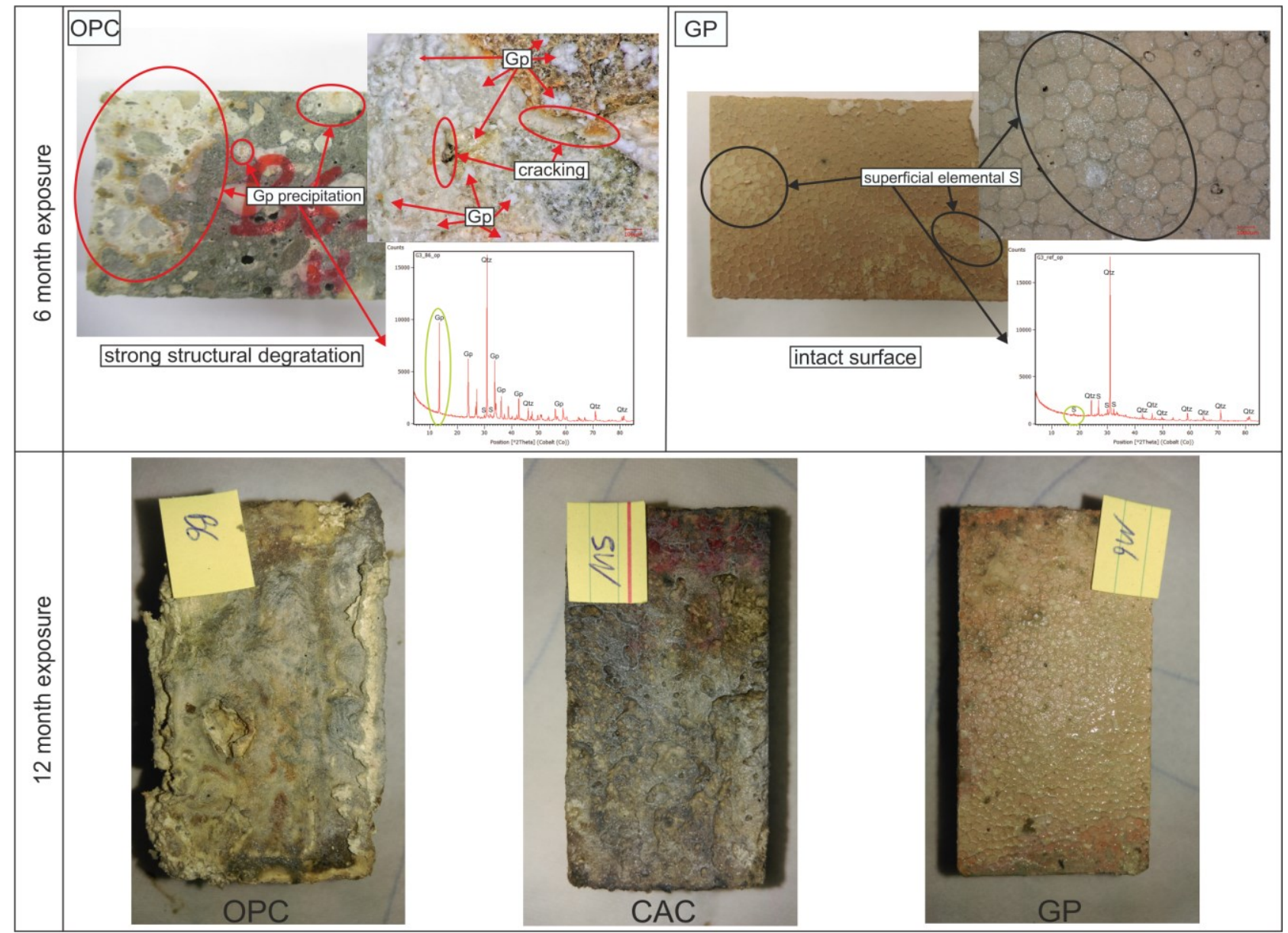

Fig. 4. Preliminary performance evaluation of ordinary Portland cement-based (OPC) and Calcium Aluminate Cement (CAC) compared to innovative, non-optimized, GP concrete (GP) after 12 months of exposure to MICC conditions. The intact surface of the GP showed insignificant elemental sulfur precipitation, while significant structural damages, such as cracking or dissolution of the cementitious matrix and coupled gypsum (Gp) precipitation, could be observed on the OPC-based materials.

The authors gratefully thank the Graz University of Technology (Austria) scientific grant program for financial support. Financial support was greatly appreciated by Peter Rappold and the Department of Water Resources Management, Styria, as well as from Heinz Lackner and the Department of Energy, Residential Constructions and Technology, Styria.

\section{References}

1. Hvitved-Jacobsen T, Vollertsen J, Nielsen AH (2013) Sewer Processes - Microbial and Chemical Process Engineering of Sewer Networks, 2nd ed. CRC Press, London

2. Berger C, Falk C, Hetzel F, et al (2016) Zustand der Kanalisation in Deutschland: Ergebnisse der DWAUmfrage 2015. Sonderdruck Korrespondenz Abwasser, Abfall. doi: 10.3242/kae2011/01.001

3. Grengg C, Kiliswa M, Mittermayr F, Alexander M (2016) Microbially-induced Concrete Corrosion- A worldwide problem. In: MicroorganismsCementitious Materials Interactions. pp 1-19

4. Jiang G, Sun J, Sharma KR, Yuan Z (2015) Corrosion and odor management in sewer systems. Curr Opin Biotechnol 33:192-197 . doi: 10.1016/j.copbio.2015.03.007

5. Grengg C, Mittermayr F, Koraimann G, et al (2017) The decisive role of acidophilic bacteria in concrete sewer networks: A new model for fast progressing microbial concrete corrosion. Cem Concr Res. doi: 10.1016/j.cemconres.2017.08.020

6. Grengg C, Mittermayr F, Ukrainzcyk N, et al (2018) Advances in mineral based construction materials for sewer systems affected by microbiological induced concrete corrosion: A review. Water Res accepted m: . doi: 10.1016/j.watres.2018.01.043

7. Pacheco-Torgal F, Labrincha J, Leonelli C, et al (2014) Handbook of Alkali- Activated Cements, Mortars and Concretes, 1st Editio. Woodhead Publishing

8. Grengg C, Mittermayr F, Baldermann a., et al (2015) Microbiologically induced concrete corrosion: A case study from a combined sewer network. Cem Concr Res 77:16-25 . doi: 10.1016/j.cemconres.2015.06.011

9. Okabe S, Odagiri M, Ito T, Satoh H (2007) Succession of sulfur-oxidizing bacteria in the microbial community on corroding concrete in sewer systems. Appl Environ Microbiol 73:971-980 . doi: 
10.1128/AEM.02054-06

10. Satoh H, Odagiri M, Ito T, Okabe S (2009) Microbial community structures and in situ sulfatereducing and sulfur-oxidizing activities in biofilms developed on mortar specimens in a corroded sewer system. Water Res 43:4729-39 . doi: 10.1016/j.watres.2009.07.035 